\title{
Disaster movie highlights transatlantic divide
} temperatures are plunging fast. Icy-cold water has swamped the streets of New York. This cinematic portrayal of the next ice age may sound harrowing, but it has left some movie-goers floundering.

In a twist worthy of a Hitchcock plot, the disaster movie The Day After Tomorrow made audiences in Germany less worried about the effects of global warming and climate change. In contrast, audiences in the United States have had their fears fuelled by the film, hinting at widely different perceptions of climate change either side of the Atlantic, according to two unpublished studies.

Since its release in May, more than 30 milrow. The film portrays the rapid arrival of an ice age after climate change shuts down the existing circulation pattern in the North Atlantic.

Currently the fifth most successful film of the year - it has grossed some US\$540 million worldwide - The Day After Tomorrow was billed as science fiction. Despite this, its plot bears a faint resemblance to what climate researchers think might happen in a future greenhouse world (see Nature 429, $347-348 ; 2004)$. But allegations of halfbaked science and panic-mongering in the movie have sparked heated debate.

Fritz Reusswig, a sociologist at the Potsdam Institute for Climate Impact Research, asked 1,200 movie-goers throughout Germany to fill in questionnaires immediately before and after they went to see the film. Most of the interviewees said that they believed climate change to be real, but the level of conviction dropped significantly after they had seen the movie (see graph).

"In a sense, the film has been counterproductive," says Reusswig, adding that the seemingly unlikely connection between 'global warming' and 'cold' may have seeded
Quirin Schiermeier, Munich

The world is in crisis. Hurricanes rage and lion adults have seen The Day After Tomor-

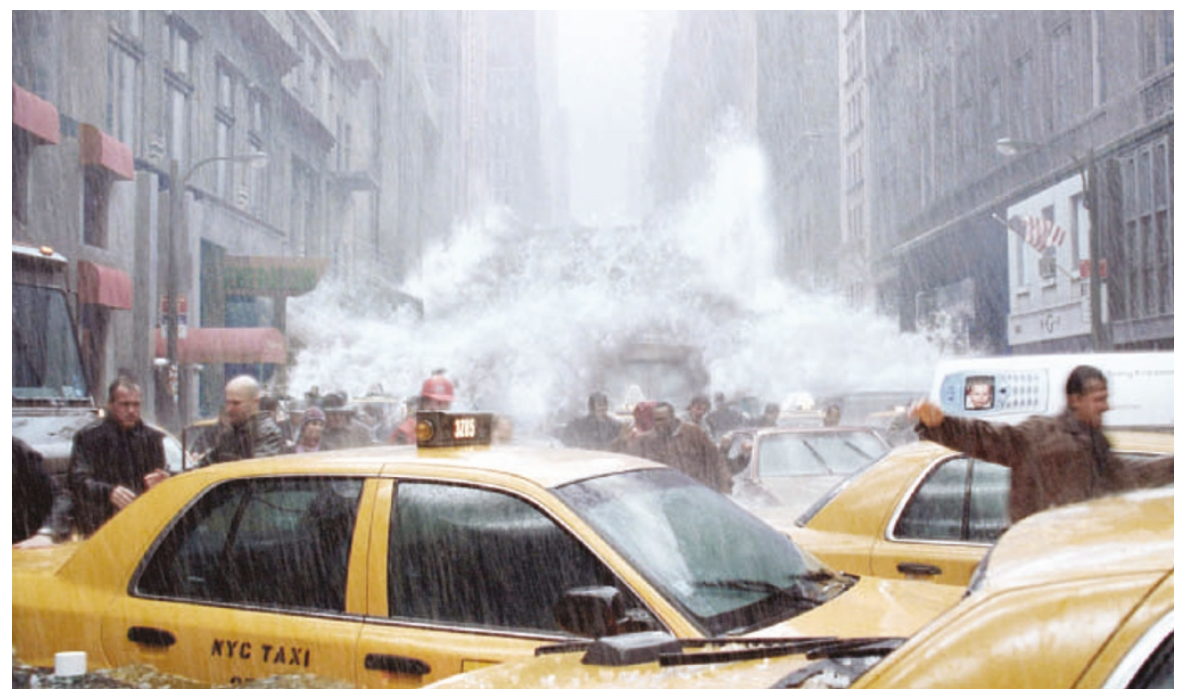

Washout: German audiences were not convinced by unrealistic events in The Day After Tomorrow.

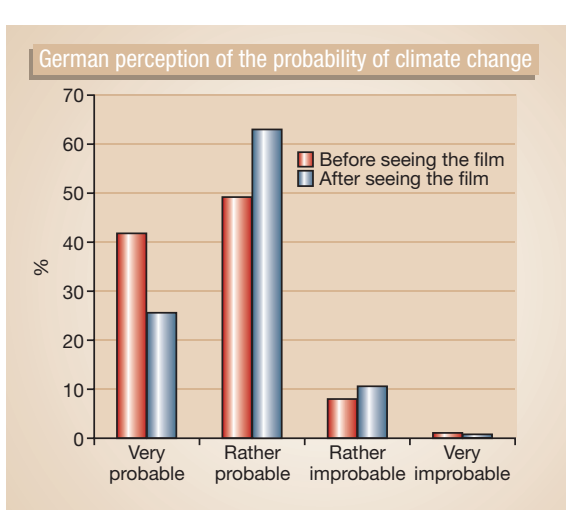

disbelief among the audience. "Most people here associate climate change with heatwaves and floods," he says. "The film has made them ask: 'If this is what climate change is like, than we are no longer sure it is real."'

But the US study - funded by the National Science Foundation — shows a different picture. Anthony Leiserowitz of Decision Research, a risk-research company based in Eugene, Oregon, conducted two

\section{Newspapers fog public view of climate change}

The US public's perception of global warming is skewed by something more pervasive than the occasional Hollywood movie, says a study released late last month. Its authors argue that people have been misled by newspaper reports that tend to give equal weight to both sides of the climate-change debate.

In the study, Maxwell Boykoff, a graduate student in environmental studies at the University of California, Santa Cruz, and his brother Jules, a visiting assistant professor of politics at Whitman College, Washington, looked at more than 600 randomly chosen articles about climate change from four major newspapers written between 1988 and 2002.
They found that $52.7 \%$ of the articles gave "roughly equal attention" to views that humans contribute to global warming and that climate change is just a result of natural fluctuations. Only $35.3 \%$ of the articles emphasized the role of humans while presenting both sides of the debate (M. T. Boykoff and J. M. Boykoff Global Environ. Change 14, 125-136; 2004).

Although it is standard journalistic practice to give both sides of a story, the Boykoffs say that this has warped public perception of an issue in which there is a strong scientific consensus. "In effect, the press has provided 'balanced' coverage of a very unbalanced issue," says Maxwell Boykoff.

Nicola Jones nationwide surveys - a week before and four weeks after the movie's release - to explore its public impact.

The results, which will be published in the November issue of Environment, revealed no evidence for a significant shift in overall public opinion, despite the media hype for the film. But of the 529 people interviewed after the film's release, half of the hundred or so who had seen it said that it had made them "somewhat or much more worried" about global warming, whereas only $1 \%$ said that they became less worried. The film even had a statistically significant impact on voting intentions among the film viewers - the survey found that overall they became slightly more likely to vote for Democrat presidential candidate John Kerry this November.

"Without doubt The Day After Tomorrow has raised awareness around the issue of climate change," says Katie Mandes, a spokeswoman for the Pew Center on Global Climate Change in Arlington, Virginia, a globalwarming think-tank. The centre's website, which explains the scientific scenario the movie depicts, more than doubled its traffic after the film's release, she says.

The different perceptions in Europe and the United States may reflect the respective levels of awareness, Mandes suggests. "Europeans are light-years ahead in accepting that climate change is a real phenomenon," she says. So most Europeans probably had a fixed notion of the effects of climate change before they went to see the film - meaning that the movie's version of events was likely to contradict their expectations.

Those waiting to watch The Day After Tomorrow at home will be treated to an extra slice of science education: the DVD, scheduled for release in October, will feature a bonus climate documentary by Los Angeles film-maker Charles Kiselyak. 